\title{
The Enhancement Quality of Squalene as a Marine Chemopreventive Agent and Vitamin A Level in The Shark Liver Oil at The Territorial Ocean of Cilacap
}

\author{
Yuhansyah Nurfauzi*, Wahyu Kurniawan, Tusrianto \\ Pharmacy Diploma Study Program, Department of Pharmacy, \\ STIKES Al Irsyad Al Islamiyyah, Cilacap, Indonesia
}

\begin{abstract}
Recently, shark liver oil is developed as mainstay product for the Cilacap fishermen proceed to be traditional supplemental foods and health product that contains squalene and Vitamin A. Squalen is one of marine natural products has demonstrated proliferative activity in animal cancer studies and may have some radioprotective effects. This observation is aimed to enhance and improve squalene acquirement quality organolepthically. This observation uses experimental observation design. Shark liver in the bottle will be proceed by the tool that specially designed to produce shark liver oil. Its result is analyzed quantitatively to gain the squalene and vitamin A level. The comparison of squalene level that has been produced in this observation is approximately from $14 \mathrm{I}$ to $19 \mathrm{I}$ higher than standard squalene product in the market. The vitamin A level in this observation is approximately 3,6 higher than shark liver oil product in the market without processing by the observation tool. The technology in the observation uses heating principle from perfect black tool that causes it more constantly hot and causes oil flow out from shark liver organ. The oil in the bowl of the tool was filtered by zeolit, so that the unpleasant or fishy smell of the oil will decrease if compared with traditional production process.
\end{abstract}

Keywords: Squalene, vitamin A, Shark liver oil, Cilacap

\section{INTRODUCTION}

Squalene is a triterpene that is an intermediate in the cholesterol biosynthesis pathway. It was so named because of its occurrence in shark liver oil, which contains large quantities and is considered its richest source (Fang et al., 2009). As we know that shark liver oil becomes mainstay product of fishermen community in Cilacap to proceed as a health product of traditional supplement foods (Kurniawan et al., 2010). The fishermen community in Cilacap do not take account for the health product quality. The oil that have been produced is a crude oil placed in the gelatin capsule.

Shark liver oil producers produces the oil based on the customer's offering. The people who consume it believe that the shark liver properties come true if regularly use the squalene and oil. Squalene in the pharmaceutical world is known as a natural healthy food that has properties to relieve and heal several diseases such as tuberculosis, skin diseases, burning wound, stomachache, liver diseases and so on.

Squalene has demonstrated proliferative activity in animal cancer studies; to date no human data are available. Squalene may have some radioprotective effects, but, again, there are no human data. Animal work suggests that squalene may also have a cholesterol-lowering effect, but this has not been tested in humans.

Squalene is a key precursor in the biosynthesis of cholesterol. It inhibits 3-hydroxy-3-methylglutaryl coenzyme A reductase activity, thus reducing farnesyl pyrophosphate availability for prenylation of the ras oncogene, an activity that could account for its anti-proliferative effect in some animal cancer models.

*Corresponding author e-mail : nur_fauzi84@yahoo.co.id 
Apoptosis inhibition may also play a role in the anti-tumor effects of squalene in animals. The mechanism of the radioprotective effect of squalene is unknown. Animal work suggests that indications could one day emerge for squalene in the prevention and treatment of some cancers, for immune enhancement and possibly for lowering cholesterol. It is not indicated for gastritis, joint pain and inflammation or to improve lung function.

Squalene is being investigated as an adjunctive therapy in some cancers. In animal models, it has proved effective in inhibiting lung tumors. It has also demonstrated chemopreventive effects against colon cancer in animal models. Supplementation of squalene in mice has produced enhanced immune function and, in other animal studies, it has reduced cholesterol levels, prompting one researcher to suggest that it might be used to potentiate cholesterol-lowering drugs. A mouse study showed squalene to confer radioprotection against lethal whole-body radiation.

Besides squalene, pharmaceutical field uses shark liver oil as source of Vitamin A, omega 3, AA and DHA. However, before we use the oil, we also should be know whether shark liver oil safe to consume by human. We must analyze all of the compound of it, not only advantage compound but also dangerous potential compound such as $\mathrm{Hg}$. Because of the potential efficacy in the pharmacy, shark liver oil production process should use the pharmaceutically efficient technology, especially in the universities that have pharmacy study program Pharmacy Study Program of STIKES Al Irsyad Al Islamiyyah Cilacap has territorial potency as public service development based on ocean resource. The ocean potency will lead to develop the competency of pharmacy students. It's so, the application of the efficient technology supports the oil product process and become lecturing material for the students to develop and improve. The activities of the public service development and the observation is aimed to produce marine pharmaceutical products. The tools that used to produce it will be promoted patented, so that it can become the university's copyright. The oil is supposed to be able to support the development of the oil producers. The potential efforts to develop are the products of healthy supplemental foods that qualified as standard of pharmaceutical products.

\section{MATERIALS AND METHODS}

\section{Analysis of $\mathrm{Hg}$ and E.coli contaminant}

Mercury $(\mathrm{Hg})$ was quantitatively analyzed by Mercury analyzer with $\mathrm{SnCl}_{2}$ reduction method and the contaminant of E.coli was analyzed with Total Plate Count (TPC) method.

\section{Production of Shark Liver Oil}

It is based on the analysis and the problem stated above that the writers have willing to apply and increase the acquirement of shark liver crude oil that contain of squalene and Vitamin A through program training and guidance to improve the method of the standard acquirement.

The applied method in this observation is actively participatory fishermen community of Scienza Jaya Mandiri that pioneered by training program such as follows:

\section{Training method of shark liver crude oil acquirement that contains of squalene and vitamin $A$}

It is based on the observation, the crude oil that acquired by fishermen community producers of Scienza Jaya Mandiri still uses manual and simple acquirement such as cutting off the shark liver and takes the liver and dried in the sun shining. The acquirement oil will be flown out to the bowl. According to our opinion that the process of acquirement oil that have been acquired does not produce the qualified shark liver crude oil optimally because it may be contaminated by ammoniac from the crude oil. The manual method stated above, the efficient technology application program makes efforts to develop the method that described on the Fig. 1. 


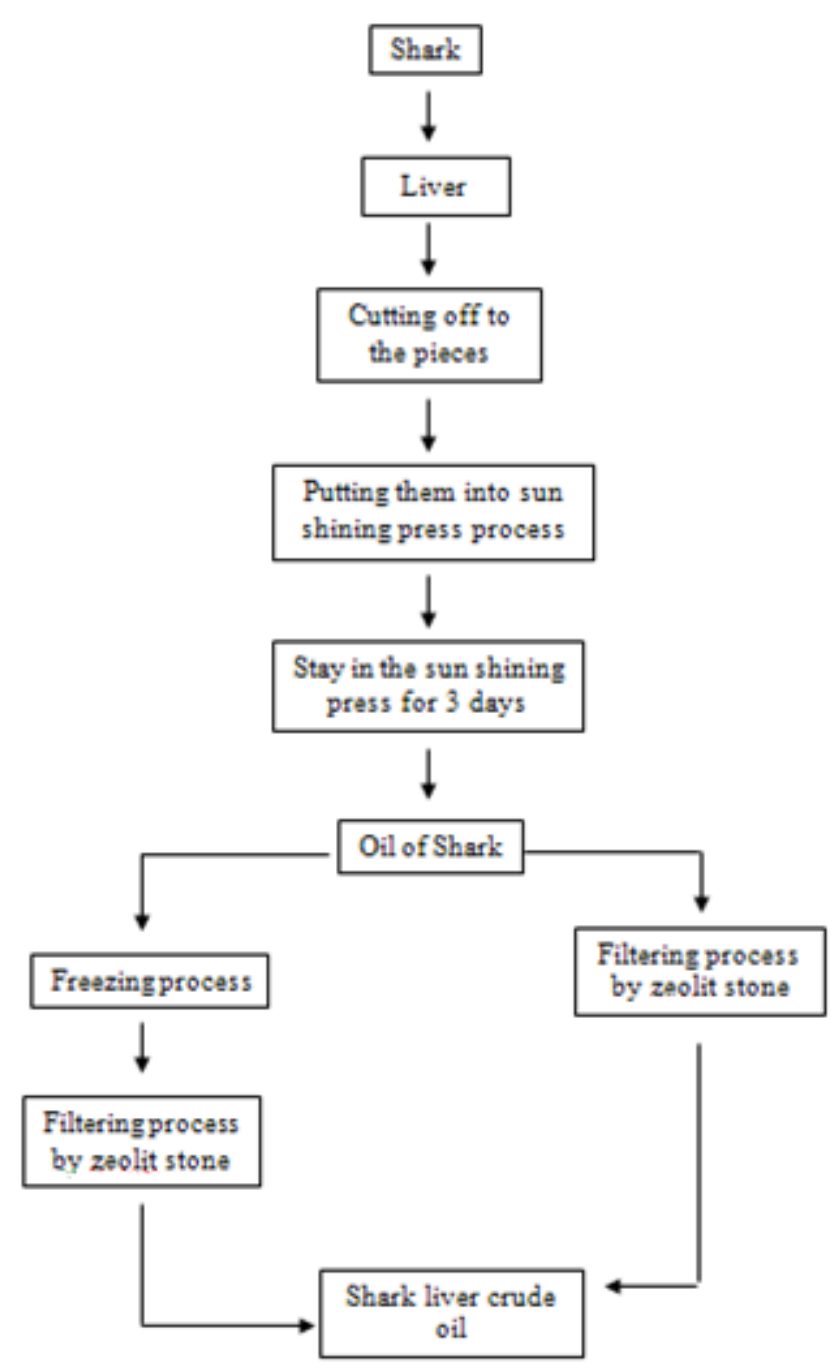

Figure I. The manual method of shark liver oil acquirement

2. Analyzing the contents of squalene and vitamin A quantitatively at laboratory.

Squalene is determined by Gas Chromatography (GC), but vitamin A level is determined by High Performance Liquid Chromatography (HPLC). Squalene level from the result of acquiring the tool is compared with standard squalene level in the market without processing by the observation tool. Vitamin A level is analyzed and compared with vitamin A level in the product of shark liver oil in the market without processing the observation tool.

\section{RESULTS AND DISCUSSION}

The result of the analysis of $\mathrm{Hg}$ and E.coli contaminant is shown on Table I. 
Table I. Result of $\mathrm{Hg}$ and E.coli analysis

\begin{tabular}{ccccc}
\hline Number & Parameter & $\begin{array}{c}\text { Examination } \\
\text { result }\end{array}$ & Unit & Method \\
\hline $\mathrm{I}$. & $\mathrm{Hg}$ & 52.55 & $\mathrm{Ppb}$ & Mercury analyzer \\
2. & $\mathrm{E}$. coli & 0 & Cfu/g & Total Plate count \\
\hline
\end{tabular}

The table shown that shark liver oil contains Mercury (Hg) 52,55 ppb or 0,05255 ppm. Fish product may contain mercury in the range $0,4-1,0$ $\mathrm{mg} / \mathrm{kg}$ or $0,4-1,0 \mathrm{ppm}$. That value fulfilled Food Safety Standard (FSS) on Japan, USA, Sweden, Finland and Canada (Nurfauzi et al., 2010). The analysis shown that there is no contaminant of E.coli. So, the shark liver oil is safe to consume by human.

After we undertake the observation in Fishermen Community of Scienza Jaya Mandiri that includes training program of refining method to acquire shark liver oil and the marketing product. So the significant result is explained as follows:

After undertaking the observation and experiment forward the product of shark liver oil that produced by the design tool, finally the result declare that the increase of acquiring vitamin $\mathrm{A}$ level is significant between the post-observation and pre-observation of training program that is explained in the table II below:

Table II. Vitamin A level in the pre-observation product of shark liver oil in the market

\begin{tabular}{ccc}
\hline Sample Number & Examination result & Unit \\
\hline $\mathrm{I}$ & 40.56 & $\mu \mathrm{g} / \mathrm{g}$ \\
2 & 18.91 & \\
3 & 17,45 & \\
\hline
\end{tabular}

The average of Vitamin A level based on table ii. $=25,6 \mu \mathrm{g} / \mathrm{g}$

Level of Vitamin A in the product of shark liver oil post-observation experimented by observation tool.
Table II. Vitamin A level in the product of shark liver oil processing with the observation tool is explained in the table III below

Table III. Vitamin A level in the product of shark liver oil processing with the observation tool

\begin{tabular}{ccc}
\hline Sample Number & Examination result & Unit \\
\hline $\mathrm{I}$ & 118.88 & $\mathrm{\mu g} / \mathrm{g}$ \\
2 & 85.48 & \\
3 & 73.13 & \\
\hline
\end{tabular}

The average of Vitamin A level based on table 3. $=92,5 \mu \mathrm{g} / \mathrm{g}$

The average of Vitamin A level that resulted by the observation compared with the product shark liver oil in the market without processing by the observation tool is 3,6 higher.
Besides Vitamin A level, squalene level in the shark liver oil pre-observation compared with postobservation, explained in the table IV below:

Table IV. Acquirement of Squalene level in the shark liver oil in the market compared with standard product squalene level in the market pre-training program

\begin{tabular}{ccc}
\hline Sample Number & Examination result & Unit \\
\hline $\mathrm{I}$ & 118.88 & \\
2 & 85.48 & $\mu \mathrm{g} / \mathrm{g}$ \\
3 & 73.13 & \\
\hline
\end{tabular}


The acquirement of squalene level in the shark liver oil product after processing with the observation tool compared by standard squalene product in the market is explained in the table $\mathrm{V}$. below

Table V. Acquirement of Squalene level in the shark liver oil after processing with the observation tool compared by standard squalene product in the market

\begin{tabular}{ccc}
\hline Sample number & $\begin{array}{c}\text { Comparison experiment result } \\
\text { at squalene level }\end{array}$ & Explanation \\
\hline 1 & $19|:|$ & Without filtering \\
2 & $168: 1$ & $\mid \times$ filtering \\
3 & $141: 1$ & $4 \times$ filtering \\
\hline
\end{tabular}

It is based on the table II and table III. above they can describe that the training program that have been undertaken can raise Vitamin A level. The result of Vitamin A level can be known based on the tables above. The acquirement of Vitamin A level which increase is caused by the touch of efficient technology applied in process of producing shark liver oil. The efficient technology in public service program uses heating principles from the tool caused by more constant heating. The heating causes oil flow out from shark liver. After flowing into the bowl at the tool, the oil is filtered by zeolit stone. The absorbed characteristic of the zeolit stone will absorb wasteful substances in the process of producing shark liver oil. It is therefore the fishy and unpleasant smell in the oil can be decreased. The observation tool results stable heating process and conditions the process if the observation is in the clean closed room. It can minimizes the outside contamination. The characteristic of zeolit stone as absorber of wasteful substances like ammoniac can be lessened, so either can the fishy and unpleasant smell.

Especially, the shark liver oil based on the observation and experiment shows better than the shark liver oil in the market because it uses the efficient technology to produce the oil. This is described by the comparison of standard oil product, namely from 141 to 191 higher than standard squalene product in the market. Organolepthically, the acquirement of shark liver oil based on the observation and experiment in public service application appears yellowish oil clearer and the sensation of fishy and unpleasant smell can be lessened.

Cilacap has squalene as a potential antitumor product. During the past few years, squalene was found to show protective activities against several carcinogens (Shentilkumar et al., 2006). Skin tumors were initiated in 50 female CD-1 mice with 7,12-dimethylbenz[a]anthracene and promoted with 12-O-tetradecanoylphorbol-13- acetate (Desai et al., 1996). The mice were treated with 5\% squalene and at the end of the prevention study, there was a $26.67 \%$ reduction in the incidence of tumors in the squalene-treated group. In a related branch of research, a protective effect was observed when squalene was given before and/or during carcinogen treatment. Experimental studies have shown that squalene can effectively inhibit chemically induced skin tumorigenesis in rodents (Smith, 2000).

This observation uses experimental observation design. Shark liver in the bottle will be proceed by the tool that specially designed to produce shark liver oil. Its result is analyzed quantitatively to gain the squalene and vitamin A level. After being analyzed, the result is compared with standard product squalene and vitamin $\mathrm{A}$ in the market. The quality aspect that evaluated is physical performance and smell, especially for the smell that makes the problem. Based on the studies above, squalene in Cilacap will be able to develop as a marine natural products for chemopreventive agents.

\section{CONCLUSIONS}

1. Vitamin A level based on the public service training program application is 3,6 higher than the oil product in the market.

2. Squalene level based on the public service training program application is approximately from 141 to 191 higher than the oil product in the market.

3. Organoleptically, the shark liver oil product and Vitamin A level based the observation and training program to acquire are yellowish clearer and the fishy and unpleasant smell can be decreased. 


\section{ACKNOWLEDGEMENT}

Thanks to DP2M DIKTI that have financed the public service training program application and its observations; The fishermen Community of Scienza Jaya Mandiri Cilacap as the partner organization; Taufan Ratri Harjanto as the design tool consultant, and Wahyudi as the Fisheries Department Consultant.

\section{REFERENCES}

Desai, K.N., Wei, H. and Lamartiniere, C.A., 1996, The preventive and therapeutic potential of the squalene-containing compound, Roidex, on tumor promotion and regression, Cancer Lett., 19, 93-96.

Fang, J.Y., Huang, Z.R. and Lin, Y.K., 2009, Biological and Pharmacological Activities of Squalene and Related Compounds: Potential Uses in Cosmetic Dermatology, Molecules, 14, 550-554.
Nurfauzi, Y., Kurniawan, W. and Tusrianto., 2010, The Enhancement of Squalene and Vitamin A Degree Quality In The Shark Liver Oil at The Territorial Ocean of Cilacap: Case Study of Traditional Supplemental Foods Safety, Proceeding, International Conference on Global Resource Conservation, Malang. ISBN: 978-602-97628-0-8, pp. 288-293, July $8^{\text {th }}$

Kurniawan, W. and Nurfauzi, Y., 2010, Upaya Meningkatkan Kualitas Perolehan Squalen pada Minyak Hati Ikan Hiu di Perairan Cilacap, Proceeding. Seminar Nasional Farmasi STIFAR. Semarang. ISBN: 978602-96450-0-2, pp.93-100, May I5, 2010.

Senthilkumar, S., Devaki, T., Manohar, B.M. and Babu, M.S., 2006, Effect of squalene on cyclophosphamide-induced toxicity, Clin. Chim. Acta, 364, 335-342.

Smith, T.J., 2000, Squalene: potential chemopreventive agent, Expert Opin. Invest. Drugs, 9, I84I-I848. 